\title{
Labyrinthe
}

$11 \mid 2002$

Numéro 11

\section{Le dernier acte est sanglant}

À propos d'une vanité de Philippe de Champaigne

\section{Karine Lanini}

\section{(2) OpenEdition}

\section{Journals}

Electronic version

URL: http://journals.openedition.org/labyrinthe/662

DOI: $10.4000 /$ labyrinthe.662

ISSN: 1950-6031

\section{Publisher}

Hermann

\section{Printed version}

Date of publication: 14 January 2002

Number of pages: 107-115

\section{Electronic reference}

Karine Lanini, «Le dernier acte est sanglant », Labyrinthe [Online], 11 | 2002, Online since 15 April 2005, connection on 04 May 2019. URL : http://journals.openedition.org/labyrinthe/662 ; DOI : 10.4000/ labyrinthe.662

This text was automatically generated on 4 May 2019.

Propriété intellectuelle 


\section{Le dernier acte est sanglant}

À propos d'une vanité de Philippe de Champaigne

Karine Lanini 